\title{
Commercial Opportunities for Productive Development of the Quinoa: A Reflection from Food Security, Sovereignty and Justice ${ }^{*}$
}

\author{
Lucy Andrea Cely Torres ${ }^{\star *}$, Julio Cesar Ducón Salas ${ }^{\star * *}$, Hadrien Lafosse ${ }^{\star * *}$
}

* Artículo de investigación

** Doctoranda en la Unión Europea, UNED. Profesora e investigadora de tiempo completo, Facultad de Ciencias Económicas y Sociales, Universidad de La Salle, Bogotá, Colombia.

Correo electrónico: 1cely@unisalle.edu.co

*** Magíster en Desarrollo Educativo y Social, CINDE. Profesor e investigador de tiempo completo, Facultad de Ciencias Administrativas y Contables, Universidad de La Salle, Bogotá, Colombia.

Correo electrónico: jcducon@unisalle.edu.co

**** Maestría en Administración de Empresas, NEOMA Business School. Profesor e investigador de tiempo completo, Facultad de Ciencias Económicas y Sociales, Universidad de La Salle, Bogotá, Colombia. Correo electrónico:

hlafosse@unisalle.edu.co

Recibido: 30 de agosto del 2016

Aprobado: 22 de enero del 2017

Cómo citar este artículo: Cely-Torres, L. A., Ducón-Salas, J. C., Lafosse, H. (2017). Commercial opportunities for productive development of the quinoa: A reflection from food security, sovereignty and justice. Cooperativismo \& Desarrollo, 111(25), 91-xx. doi: https://doi.org/10.16925/ co.v25i111.1877

\begin{abstract}
Purpose: Food security is one of the most pressing issues of our century because of its implications for the future. To that extent, this article is a preliminary attempt to shed light on the opportunities stemming from the commercialization of quinoa. Description: We undertook this study to try and grasp why the Cosmovision of Andean populations consider quinoa as an alternative for development. We first go through some aspects of food security, sovereignty and justice, which will eventually lead us to take a closer look at quinoa's proper characteristics and production process. We will complement our study by an analysis of data on the commercialization of quinoa in order to evaluate its opportunities internationally. Conclusions: Quinoa presents very interesting nutritive characteristics, offers a variety of seeds, is relatively easy to grow virtually anywhere and can be used in a number of byproducts. To that extent, it should be seriously considered as a palatable solution to the global food crisis.
\end{abstract}

Keywords: development, food, innovation, sovereignty, trade. 


\section{Oportunidades comerciales para el desarrollo productivo de la quinoa: una reflexión desde la seguridad alimentaria, la soberanía y la justicia}

\section{Resumen}

Objetivo: la seguridad alimentaria es uno de los temas más apremiantes de nuestro siglo debido a sus implicaciones para el futuro. En este sentido, el presente artículo es un intento preliminar que busca arrojar luz sobre las oportunidades derivadas de la comercialización de la quinua. Descripción: la razón para emprender este estudio fue tratar de comprender por qué la cosmovisión de las poblaciones andinas considera la quinua como una alternativa para el desarrollo. Se hace una revisión inicial de algunos aspectos de la seguridad alimentaria, la soberanía y la justicia, lo que finalmente conduce a una exploración más detallada de las características de la quinua y su proceso de producción. El estudio se complementa mediante un análisis de datos sobre la comercialización de la quinua, con el fin de evaluar sus oportunidades a nivel internacional. Conclusiones: la quinua presenta características nutritivas muy interesantes, ofrece una variedad de semillas, es relativamente fácil de cultivar -prácticamente en cualquier lugar-, y puede utilizarse en varios subproductos. En esa medida, debe considerarse seriamente como una solución posible y apetecible a la crisis alimentaria mundial.

Palabras clave: desarrollo, alimentación, innovación, soberanía, comercio

\section{Oportunidades comerciais para o desenvolvimento produtivo da quinoa: uma reflexão a partir da segurança alimentar, da soberania e da justiça}

\section{Resumo}

Objetivo: a segurança alimentar é um dos temas mais urgentes do nosso século devido a suas implicações para o futuro. Nesse sentido, este artigo é uma tentativa preliminar de mostrar as oportunidades derivadas da comercialização da quinoa. Descrição: a razão para empreender este estudo foi tentar compreender por que a cosmovisão das populações andinas considera a quinoa como uma alternativa para o desenvolvimento. Faz-se uma revisão inicial de alguns aspectos da segurança alimentar, da soberania e da justiça, o que finalmente conduz a uma exploração mais detalhada das características da quinoa e de seu processo de produção. Além disso, ele é complementado por uma análise de dados sobre a comercialização da quinoa a fim de avaliar suas oportunidades no contexto internacional. Conclusões: a quinoa apresenta características nutritivas relevantes, oferece uma variedade de sementes, é relativamente fácil de cultivar - praticamente em qualquer lugar-e pode ser utilizada em várias subprodutos. Nessa medida, deve ser considerada seriamente como uma solução possível e desejável para a crise alimentar mundial.

Palavras-chave: alimentação, comércio, desenvolvimento, inovação, soberania. 
Ahorita, este año, el quintal de maíz llegó a valer en esta comunidad 180 quetzales, porque no hubo producción. Pero cuando hay producción y nosotros queremos vender, nos vienen a pagar a 45. Lo hemos hablado y nosotros queremos producir, pero no vender, porque luego nos toca comprarlo más caro.

Raquel Vásquez, campesina guatemalteca

Obra Social "la Caixa" (2012)

\section{Introduction}

Since the World Food Summit in Rome, Italy in 1996, putting an end to hunger and malnutrition and guaranteeing the sustainability of food supply globally have been top on the agenda of the food security debate. These three objectives are reflected in the commitments of the participating countries in the summits that followed and have helped build a framework of analysis and discussion, and most importantly focus on possible solutions.

The first dimension of food security is the availability of food supply (Figure 1), which in turn can be broken down into two concepts: collection of food and economic access to food. To that extent, we could set out that food security lies in the existence of an actual and fair possibility as far as supply is concerned.

In the same vein, the relationship between production and supply must be maintained to a certain level in order to meet the minimum well-being requirements of humankind, more specifically in terms of a healthy and active life.

The second dimension of food security has to do with the economic and physical access to food. This second dimension sheds light on the social aspect of food supply and emphasizes the significance of policies that aim at guaranteeing the sufficiency of essential foods to satisfy the physiological needs, and provide for the nutritional wellbeing of the human being. An illustration would be policies that enable access to drinking water and medical attention. Additionally, it is important to point out that the significance of supply is also determined by its timeframe, namely populations cannot run the risk of lacking food supply in times of economic or environmental crises.

The third dimension of food security focuses on the use of food. More specifically, it refers to the optimal use of the nutrients provided by food in order to allow healthy diets and ultimately improve people's health.

Finally, the last dimension of food security addresses the stability of the three aforementioned components. Indeed, the stability of food security depends on the implementation of plans and actions that can guarantee supply, access and consumption of food in spite of the many social, economic and environmental risks that might jeopardize food supply.

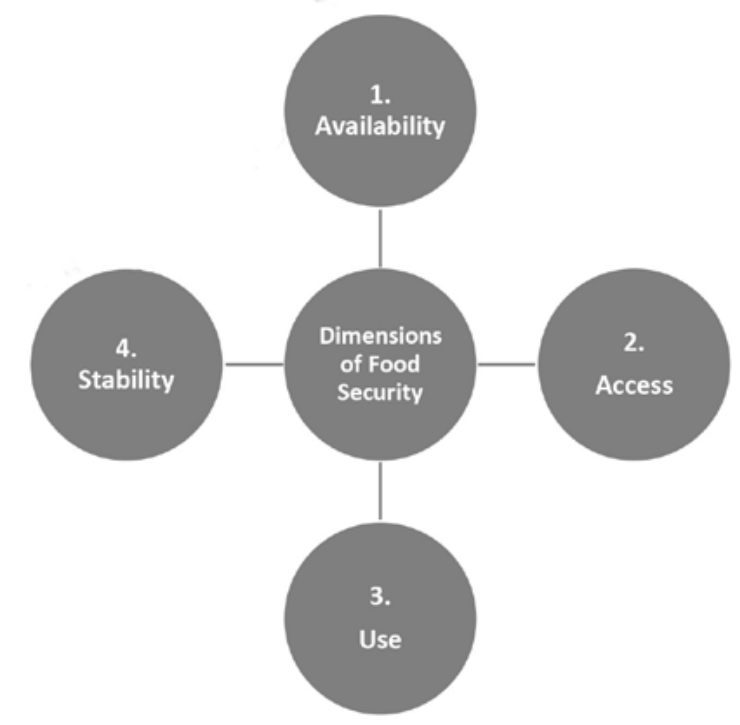

Figure 1. The dimensions of food security. Source: Adapted from Informe de políticas: seguridad alimentaria, por FAO, 1996.

According to the definition given during the World Food Summit of 1996, "Food security exists when all people, at all times, have physical and economic access to sufficient, safe and nutritious food that meets their dietary needs and food preferences for an active and healthy life" (FAO, 2011). The different concepts presented in this definition are intertwined: to that extent, it is essential to have all the elements of this definition reunited at the same time to guarantee the possibility of reaching food security, most importantly for those vulnerable populations or communities that are most exposed to deprivation and who do not benefit from the implementation of policies aiming at food security.

Based on the analysis of the four dimensions of food security as outlined in table 1 above, we assume that in order to reach food security it is essential to design sustainable structural public policies. For instance, in order for populations to have access to enough quality food, one country has to implement efficient systems of supply to guarantee its availability. That in turn, and as a prerequisite, requires such country to strengthen its production apparatus and/or increase its imports to guarantee the expected availability of quality food. Therefore, it is relevant to consider access to food as social entitlement and part of the bare necessities. 
Table 1

Approach to Food Security

\begin{tabular}{|c|c|c|c|}
\hline Double Focus & Availability & Access and Use & Stability \\
\hline \multirow{11}{*}{$\begin{array}{l}\text { Rural development } \\
\text { and increase of } \\
\text { productivity }\end{array}$} & $\begin{array}{l}\text { Increased food supply for the most } \\
\text { vulnerable }\end{array}$ & $\begin{array}{l}\text { Reestablishment of rural } \\
\text { institutions }\end{array}$ & $\begin{array}{l}\text { Diversification of agriculture } \\
\text { and jobs }\end{array}$ \\
\hline & $\begin{array}{l}\text { Increased rural production of food } \\
\text { (small producers) }\end{array}$ & Increased access to assets & $\begin{array}{l}\text { Follow-up on food security } \\
\text { and vulnerability }\end{array}$ \\
\hline & Investment in rural infrastructure & Guaranteed access to land & $\begin{array}{l}\text { Reintegration of refugees and } \\
\text { displaced populations }\end{array}$ \\
\hline & Revitalization of the cattle industry & $\begin{array}{l}\text { Reactivation of the rural } \\
\text { funding systems }\end{array}$ & $\begin{array}{l}\text { Promotion of risk analysis } \\
\text { and risk management }\end{array}$ \\
\hline & Preservation of resources & Strengthening of the job market & $\begin{array}{l}\text { Reactivation of access to } \\
\text { credit and savings systems }\end{array}$ \\
\hline & Increased income and right to food & $\begin{array}{l}\text { Mechanisms to ensure the } \\
\text { harmlessness of food }\end{array}$ & \\
\hline & \multicolumn{3}{|c|}{ Social rehabilitation programs } \\
\hline & Food aid & Food and cash transfers & $\begin{array}{l}\text { Reestablishment of social } \\
\text { protection networks }\end{array}$ \\
\hline & Seeds and supplies & Redistribution of assets & $\begin{array}{l}\text { Follow-up on immediate } \\
\text { vulnerability and impact of } \\
\text { interventions }\end{array}$ \\
\hline & Promote the revival of the market & Social rehabilitation programs & Activities fomenting peace \\
\hline & & Nutrition programs & \\
\hline
\end{tabular}

Source: Adapted from Pingali \& Jacky (2005), cited in Informe de políticas: seguridad alimentaria, by FAO, 2006.

According to the Food and Agriculture Organization of the United Nations (2011), if stability of availability, access and use of food is to be reached, two underlying conditions have to be met: sustainable rural development and the implementation of access programs in the sectors that most need them. Based on these two elements, it is necessary to create a series of actions promoting the development of efficient food systems in which the use of technology, the diversification of production, and the market -relationship between producers and consumersshould not only help meet the very purpose of food security, but they should do so in a sustainable fashion. In addition, it is important to support the most vulnerable populations through processes of inclusion in the face of inequality and hurdles to access food. 
Taking into account the participating countries' praiseworthy commitments in terms of food security in the course of the last few decades, FAO presented in 2015 its report on world food insecurity. In this report, it is highlighted that the United Nations Millennium Development Goal of "halving between 1990 and 2015 the proportion of people who suffer from hunger" (United Nations, n.d.) had progressed significantly although that target was not fully met. More specifically, it was found that 72 of the 129 had complied with the United Nations Millennium Development Goals and that 29 of those 129 managed to halve the number of underfed people within their populations.

As outlined in figure 2, from the period 19901992 - taken as a basis for the definition of the MDGs - until 2005, the number of underfed people went down by $4.8 \%$. On the other hand, it is to be reported that from 2005 to 2015 the drop in the global number of underfed people is even more substantial since it decreased $17 \%$. These advances are accounted for by the commitments made and successes achieved in developing regions such as Latin America, Central, Eastern, and Southeastern Asia, Caucasus, and Northern and Western Africa. As far as the Caribbean, Southern Asia, Oceania, Eastern and Southern Africa are concerned, significant advances have been reported although they came short of reaching the objective of halving the proportion of people suffering from chronic underfeeding (FAO, 2015).

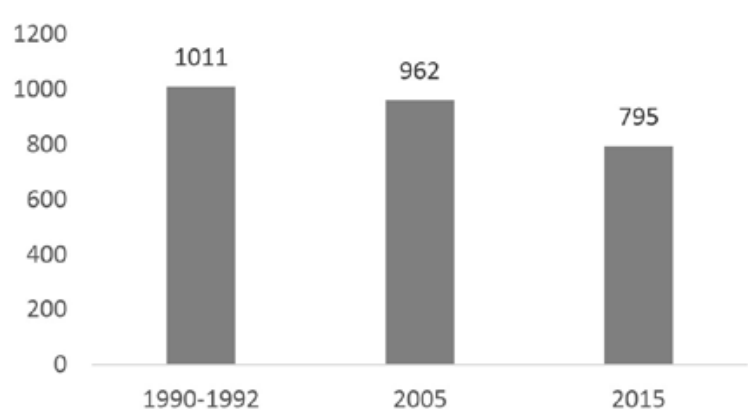

Figure 2. Number of underfed people globally (millions).

Source: Adapted from El estado de la inseguridad alimentaria en el mundo, by FAO, 2015.

The latter is a reminder that the global issue of food security is complex. Indeed, and as was mentioned earlier, food security is better defined through four components - availability, access, use and the stability of them three-. The very stability of these three components is guaranteed by two underlying factors: sustainable rural development and the implementation of access programs in the sectors that most need them. To that extent, the variety of considerations within the concept of food security calls for a series of responses ranging from plans to alleviate poverty and foment job opportunities, to the implementation of public health policies.

Given the dire situations many people across the globe live in (droughts, depletion of land, desertification, and unpredictable climate, to mention a few), the debate on food security has intensified. This is a reminder of the significance of food security and more specifically of two of its components, i.e. availability and access to food for the present and future (OXFAM, 2011).

According to the political declaration of the 2002 Rome NGo/cso Forum for Food Sovereignty, food sovereignty is defined as "the right of peoples, communities, and countries to define their own agricultural, labor, fishing, food and land policies which are ecologically, socially, economically and culturally appropriate to their unique circumstances" (FAO, 2002). To that extent, it becomes obvious that food sovereignty is inherently political. In that regard, it is relevant to highlight that this declaration from the 2002 Rome Forum stems from the opposition to the outcome of the 1996 World Food Summit, which allegedly supported neoliberal policies ultimately harming communities around the world through the opening of national markets to the "dumping" of agricultural products and privatization of basic social services among others (FAO, 2002).

Because of this, many groups - farmers, fishermen, unions, women's rights organizations- have echoed the importance of protecting food sovereignty through many demonstrations. Incidentally, food sovereignty is defined as the preemptive entitlement of people to food and production of the same, which, to put it another way, comes down to an entitlement to supply and consumption.

Under those circumstances, food sovereignty requires structural changes, which range from the improvement of production processes to the adjustment of food distribution and consumption (Table 2). 
Table 2

The Fundamentals of Food Sovereignty

\begin{tabular}{ll}
\hline \multicolumn{1}{c}{ Actions } & \multicolumn{1}{c}{ Description } \\
\hline Changes in public agricultural policies. & $\begin{array}{l}\text { Promotion of policies favoring food systems based on food } \\
\text { entitlement, forbidding speculation and seizure of resources such as } \\
\text { land and water. }\end{array}$ \\
\hline Land rights, seeds and common property. & $\begin{array}{l}\text { Opposition to the commercialization of common property such as } \\
\text { land, seeds, water, trees, woods, air and knowledge. }\end{array}$ \\
\hline Changes in production and consumption. & $\begin{array}{l}\text { Setting up of local production systems that provide safe and healthy } \\
\text { food to all while preserving biodiversity and natural resources. }\end{array}$ \\
\hline Changes in the distribution of food. & $\begin{array}{l}\text { Promotion and diversification of local markets based on solidarity } \\
\text { and fair prices, shortening distribution channels and thus } \\
\text { minimizing big retailers' bargaining power. }\end{array}$ \\
\hline Improvement in social and working conditions. & $\begin{array}{l}\text { Ban on the exploitation and deterioration of social and working } \\
\text { conditions for women and men that work in the fields and in food } \\
\text { transformation processes. }\end{array}$ \\
\hline
\end{tabular}

Source: Compiled by the authors based on data taken from FAO.

As can be derived from table 2, the main concern comes from the control multinationals wield over the food production chain, which sheds light on the existing tensions between people's rights and retailers' commercial interests.

Ecuador is one of the most eloquent examples regarding food sovereignty. Indeed, the country has focused on giving added value mostly to Andean crops based on an alternative paradigm in order to stimulate the rural economy, and simultaneously promote healthier and informed consumption. This model is built on the consolidation of traditional output taking into account three elements: the relationship between crops and the food system, the relationship between knowledge and production, and the ways of life. The implementation of this model generates benefits for the rural populations in terms of quality of life, building of skills and value added.

A third very important aspect of food security is justice. According to the Royal Spanish Academy dictionary, the concept of justice can be comprehended in two different ways. The first interpretation of justice focuses on giving each individual what they deserve or what they own. The second explanation of justice has to do with doing what is reasonable or fair. Nonetheless, a quote of Mahatma Gandhi might sum it all up better: "Earth provides enough to satisfy every man's needs, but not every man's greed".

From the food perspective, justice bears an ethical aspect that is related with production and consumption in a world that has to deal with climate change, loss of biodiversity, population growth, increasing energy prices, a significantly growing demand for meat and dairy products, and the race for land ownership (biofuels, industry and urbanization; OXFAM, 2011).

A point often overlooked is that $70 \%$ of global decisions made on food are in the hands of as few as 500 multinational companies. It is also important to realize that only three food companies control $90 \%$ of the world trade of grain. Another key point, and most compelling evidence, is that in 2005 , the profits of the number one retailer in the world exceeded the GDP of all the low-income countries combined (Obra Social de la Caixa, 2012). All things considered, it becomes clear that food justice is not exclusively an issue of distribution of production, but more than anything of imbalance and inequality.

According to figure 3, very few companies such as Monsanto, Syngenta and Dupont - to name the most famous of them all- have tight control over seeds, pesticides, food and trade. These companies have jeopardized small farmers and retailers and have significantly contributed to the deterioration of the living conditions of many communities in terms of inequalities and environmental damage, such as depletion of soil, desertification, water shortage, to mention a few. Those communities are under the yoke of big business that arbitrarily fixes unfair prices to better serve their interests (OXFAM, 2011). Be that as it may, it raises the question of these companies' social responsibility in terms of food justice and highlights the lack of implementation of socially responsible practices regarding prices, waste, and food quality. 


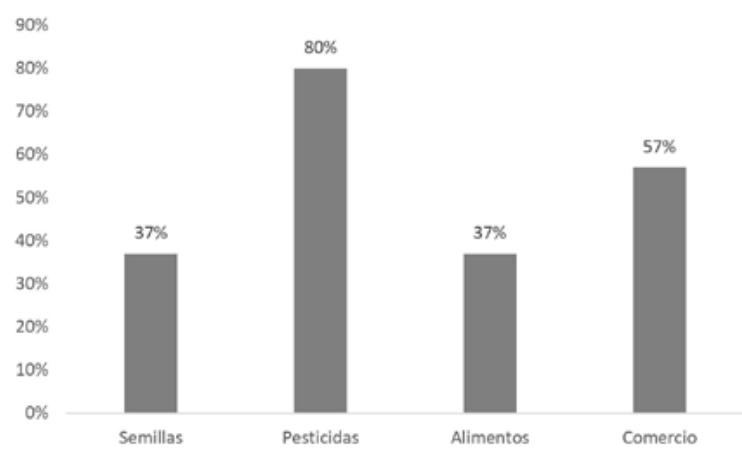

Figure 3. Percentage of the global food market in the hands of Syngenta, DuPont, Monsanto and another 7 multinationals. Source: Compiled by the authors based on data taken from Coordinadora Estatal de Comercio Justo (CECJ).

According to Bojanic (2011), FAo Representative for Latin America, inflation affects negatively the poorest countries' nutrition indexes, not only because it directly reduces their access to food but most importantly because it leads to a change in diets where cheap food replaces quality food (Álvez, 2011). For this reason, back in 2011, some organizations like FAO, IFAD ${ }^{1}$, and $\mathrm{WFP}^{2}$ highlighted the emergency to come up with specific solutions as far as waste and food loss in developing and developed countries are concerned. In the case of Latin America today, some have blown the whistle regarding the risk of dependency from imports when it comes to the volatility of the prices of inputs and products. Under those circumstances, FAO has urged Latin American countries to recover ancestral dietary traditions. Indeed, Andean crops have historically been a central part of the dietary habits of native populations granted their exceptional nutritional value - quinoa for instance - and because they bear better comparative and competitive advantages to yield organic crops specifically.

Henceforth, and based on the discussion above, one could ask the following questions: what could be the contribution of Andean crops of quinoa to the food security debate in Latin America? Beyond Latin America, what are the international trade opportunities for quinoa?

1. International Fund for Agricultural Development

2. World Food program

\section{Commercial Opportunities for Andean Crops: The Case of Quinoa}

The drastic changes brought about by the internationalization of the economies have focused the interests of the food industry on productivity. To that extent, internationalization is considered a competitiveness strategy in which two types of factors are essential: the "basic" factors - natural resources, climate, location, geographical data-, and the "advanced" factors - research centers, industrial specialization, and technological capacity for the development of production processes-. Nonetheless, in order for these factors to turn into national competitive advantages, it is necessary for both businesses and the state to cooperate through training policies, the setting up of production standards, the regulation of capital markets and the regulation of monetary and commercial policies - customs duties, agricultural subsidies, quotas, local content requirement, trade agreements among others-.

Given these points, it is relevant to further investigate quinoa. Indeed, the production of quinoa has dramatically increased in Bolivia, Peru and Ecuador, whose combined production today represents $80 \%$ of global production of quinoa. In that regard, it is necessary to realize that the concentration of quinoa production is not only due to its origin (the Andes), but most importantly to the actions taken by the respective governments to stimulate the growth in the production and commercialization of this crop.

One of the main characteristics of the production of quinoa is that small farm owners generally grow it organically, which guarantees high nutritional values. As a result, and because of its high concentration in amino acids - nutritious-, easy access - adaptable to different climates and soils, and low associated costs of production - and organic use, quinoa is considered strategic, with the potential to substantially contribute to food security and sovereignty (Bojanic, 2011).

In addition, another characteristic of quinoa worth mentioning is its genetic variety: indeed, it is estimated that there are over twenty-five varieties, nine of which are produced in Europe and the remaining 16 in Latin America. This variety is key to food security for those regions of the world which do not have access to protein sources or where the production of food is limited (Table 3). 
Table 3

Varieties of Quinoa per Continent

\begin{tabular}{|c|c|c|}
\hline 1 & Variedades europeas & Dinamarca \\
\hline 2 & & Inglaterra \\
\hline 3 & & Inglaterra \\
\hline 4 & & Holanda \\
\hline 5 & & Dinamarca \\
\hline 6 & & Grecia \\
\hline 7 & \multirow{19}{*}{$\begin{array}{l}\text { Variedades } \\
\text { latinoamericana }\end{array}$} & Brasil \\
\hline 8 & & Chile \\
\hline 9 & & Perú \\
\hline 10 & & Perú \\
\hline 11 & & Perú \\
\hline 12 & & Perú \\
\hline 13 & & Colombia \\
\hline 14 & & Perú \\
\hline 15 & & Bolivia \\
\hline 16 & & Bolivia \\
\hline 17 & & Bolivia \\
\hline 18 & & Argentina \\
\hline 19 & & Bolivia \\
\hline 20 & & Ecuador \\
\hline 21 & & Perú \\
\hline 22 & & Perú \\
\hline 23 & & Ecuador \\
\hline 24 & & Chile \\
\hline 25 & & Perú \\
\hline
\end{tabular}

Source: Adapted from Perspectivas alimentarias, by FAO, 2013.

At present, production of quinoa is concentrated in the hands of small farm owners in the high Andean Plateaus of Peru and Bolivia, and in the high lands of Ecuador. Figure 4 features the yields in USD and volume of the main producers of quinoa. This figure shows that the main chunk of the market is divided among Peru, Bolivia and Ecuador to a lesser extent (Montoya \& Martínez, 2005).

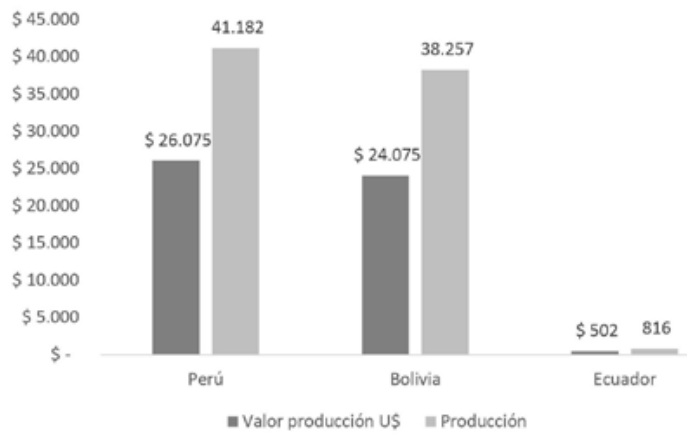

Figure 4. Main producers of quinoa in USD and volume (2012). Adapted from Tendencias y perspectivas del comercio internacional de quinua. Source: by FaO, 2012. 
Although quinoa can be grown virtually in any type of soil, Peru and Bolivia stand out by the amounts they produce because they make the most of their comparative advantages. For instance, according to the Peru Ministry of Agriculture, Peru optimized the possibility of growing quinoa on its coastline specifically. In addition, in terms of its commercialization, Peru enhanced its infrastructure, thus facilitating exports to the international markets in order to reap full benefits from its trade agreements (Table 4).

Table 4

Main Producers of Quinoa (Thousands of Tons)

\begin{tabular}{|c|c|c|c|c|c|c|c|c|c|}
\hline País & 2005 & 2006 & 2007 & 2008 & 2009 & 2010 & 2011 & 2012 & 2013 \\
\hline Perú & 32,6 & 30,4 & 31,8 & 29,9 & 39,4 & 41,1 & 41,2 & 44,2 & 52,1 \\
\hline Bolivia & 25,2 & 26,9 & 26,6 & 27,2 & 34,2 & 36,7 & 40,9 & 45,8 & 50,5 \\
\hline Otros & 0,7 & 0,7 & 0,7 & 0,7 & 0,8 & 0,9 & 0,8 & 0,8 & 0,8 \\
\hline Munidal & 58,4 & 58 & 59,1 & 57,8 & 74,4 & 78,7 & 82,9 & 90,8 & 103,4 \\
\hline
\end{tabular}

Source: Adapted from Perspectivas alimentarias, by FAO, 2013.

As far as imports are concerned (Figure 5), the United States is by far the first importer of quinoa in the world (53\%), followed by Canada (15\%), France $(8 \%)$, the Netherlands (4\%), Germany (4\%), ALADI (3\%), Australia (3\%) and the United Kingdom (2\%).

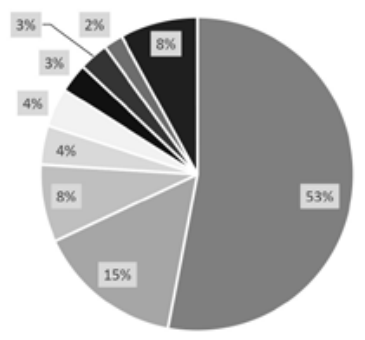

Figure 5. Percentage of imports of quinoa per country. Adapted from Perspectivas alimentarias. Source: by FAO, 2013.

In terms of regional exports of quinoa, Bolivia has historically been the first exporter of quinoa in Latin America, followed by Peru and Ecuador. Yet, some changes in that pattern have occurred over the last two decades. Indeed, as depicted in figure 6 below, Bolivia's share of exports diminished from $90 \%$ of the total of the region over the period $1992-1996$, to $75 \%$ of the total for the period 2008-2012. This finding is accounted for by the increase in the stake of Peru, whose share in regional exports grew from $6 \%$ for the timeframe 1992-2006 to $23 \%$ for the timeframe $2008-2012$.

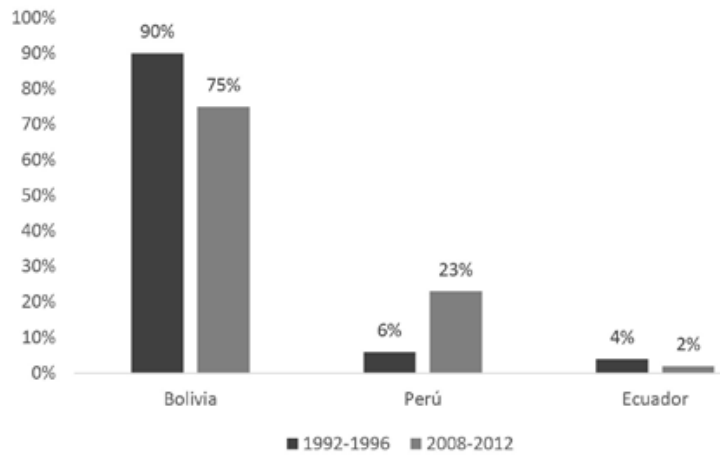

Figure 6. Comparison of total exports of quinoa (\%) for the main producers in the Andean region.

Adapted from Tendencias y perspectivas del comercio internacional de quinua. Source: by FAO and ALADI, 2012.

It is important to realize that both the number of target countries for the exports of quinoa and the volume of exports themselves have increased markedly from 1992 to 2008. In that regard, the number one importer is the United States, having increased its share from $34 \%$ to $56 \%$ over the period of analysis. In addition, figure 7 below draws our attention to the appearance of new actors on the map of importing countries, namely Canada, Australia, Brazil and Israel, among others. 


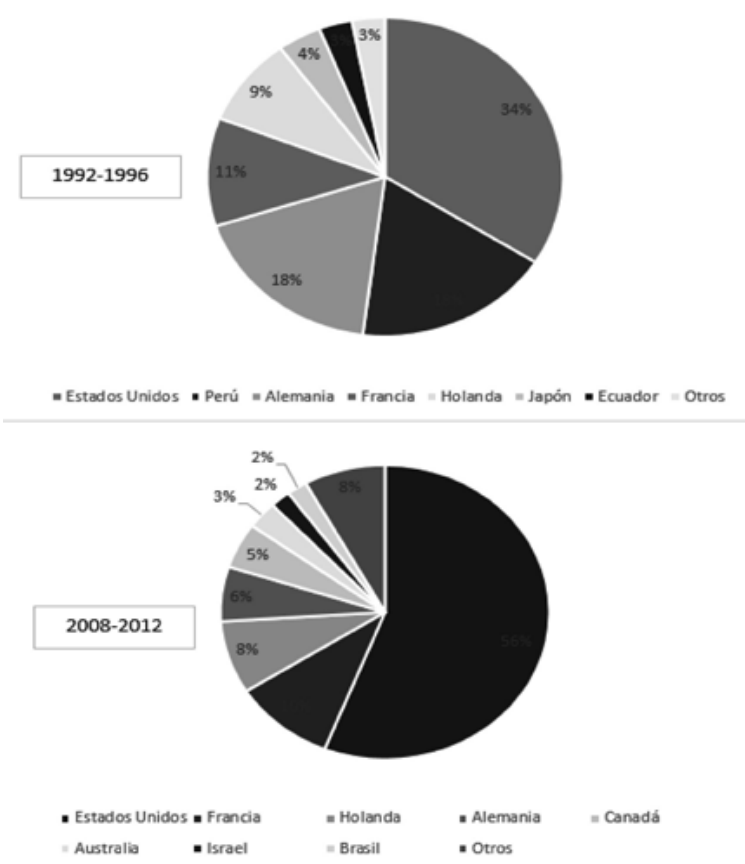

Figure 7. Shares (\%) of imports of quinoa per country. Source: Compiled by the authors based on data taken from FAO.

According to figure 8, during the period 1992-2007 it can be observed that FOB export prices of quinoa have remained mostly steady fluctuating very little from USD 1.1to USD 1.3 per kg. From 2007 to 2009, the price of quinoa soared going from USD 1.3 to USD 3 per kg. Yet, from 2009 until 2012, the price leveled off at USD 3 per $\mathrm{kg}$. The sharp boom in prices of quinoa from 2007 to 2009 reflects the boost in global demand for this crop.

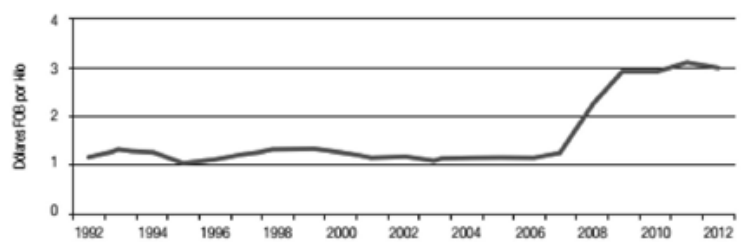

Figure 8. Behavior of quinoa export prices 1992-2012. Source: Compiled by the authors based on data taken from FAO.

As can be derived from the figure 8 it is clear that the prospects for the producers and the distributors of quinoa have greatly improved only because quinoa has enjoyed wide success in international markets. On the other hand, it is important to stress that a series of byproducts have been developed on the basis of quinoa such as flours, noodles, flakes, energy bars, and with the help of technology, even natural oil. More particularly, the production of protein concentrates stands out for its great marketing potential. Overall, there is no denying that quinoa has a competitive advantage, more specifically so when it comes to the commercial potential for the range of byproducts derived from it (Table 5).

Table 5

Traditional and Non-Traditional Foods Made from Quinoa

\begin{tabular}{ll}
\hline Preparado & Tipo de alimento \\
\hline Sopas y segundos & $\begin{array}{l}\text { Sopa de quinua, lawa, juchacha, chiwa de quinua, p'esque con ahugado, mazamo- } \\
\text { rra, phiri, p'hsira (graneado), p' esque huracha, p'esque con leche, p'esque con } \\
\text { queso }\end{array}$ \\
\hline Masas & $\begin{array}{l}\text { Kispiña, mucuna, buñuelos, pan, galletas, kispiña de ajara, tortas de quinua, } \\
\text { tortillas de quinua, tacti o tactacho, mululsito quispiña, kispuiña de ajara, k'api } \\
\text { kispiña, acu kispiña, jupha t' anta, buñuelos de quinua, kaswira de quinua, queque } \\
\text { de quinua, turucha kispiña, quichi quispiña }\end{array}$ \\
\hline Bebidas & Refresco (ullpu(; qúsa (chicha), api \\
\hline Merienda seca & Pito de quinua \\
\hline
\end{tabular}

Note. Adapted from "Análisis de las variables estratégicas para la conformación de una cadena productiva de la quinua en Colombia”. Source: L. Montoya \& L. Martínez, 2005, in Revista Innovar, 15.

On top of the different uses of quinoa mentioned above, a point often overlooked is that quinoa can also be used in other industries, for instance, the pharmaceutical industry or the cosmetics industry. This very consideration has led Peru and Bolivia to consider quinoa as a complete production chain because of the many possibilities it offers (Figure 9). 


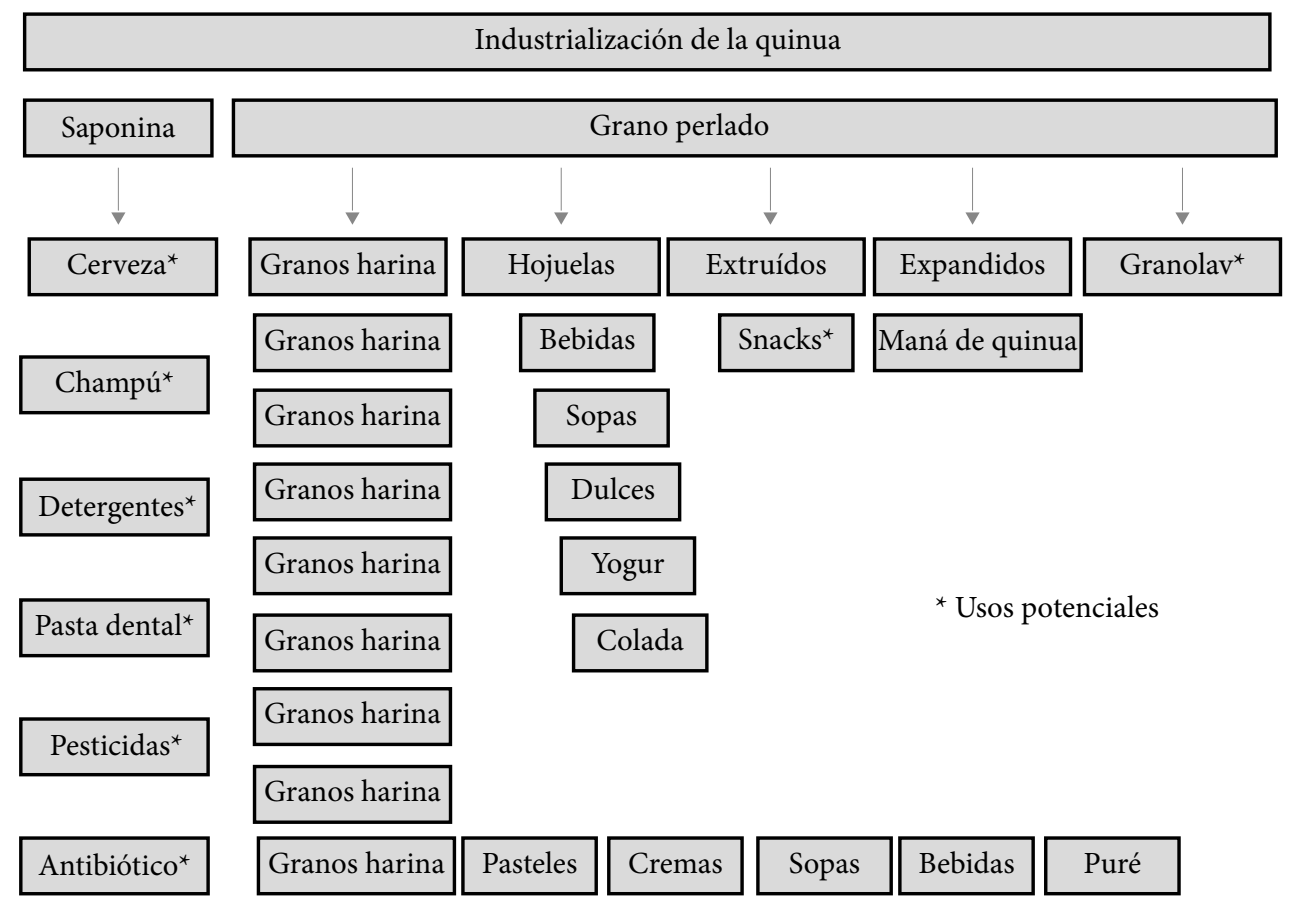

Figure 9. Productive chain of quinoa. Adapted from Perspectivas alimentarias. Source: by FAO, 2013.

Regarding quinoa as a chain of production allows us to contemplate the many commercial opportunities it offers not only locally but also internationally. Nonetheless, in order to build processes that allow to comprehend the full dimension of the commercial opportunities associated with the farming of quinoa, it is necessary to carry out research that leads to the development of practices, processes and innovative products - finished goods for instance - that result in value added.

Traditionally, the process of growing quinoa is broken down into a series of steps that allows to obtain the grain. This process starts with the preparation of the seedbed, sowing of the seeds, and local practices - weeding, fertilizing-. The next step is the harvest, including piling up the grain, threshing it and putting it out to dry. Then comes the post-harvest phase, including cleaning and storing of the grain (Pérez, 2014). The last step boils down to the process of lowering the saponin content in order to obtain the final quinoa grain called "quinua perlada".

The production costs of quinoa are characterized by a relatively low investment in agricultural inputs. According to the Peru Ministry of Agriculture (MI$\mathrm{NAG}$ ), regarding the agriproductive chain of quinoa in 2013, the structure of costs was the following:
Table 6

Direct Costs of Production in Peru in 2013

\begin{tabular}{llc}
\hline \multicolumn{1}{c}{ DIRECT COSTS OF PRODUCTION } & US\$/Ha & $\%$ \\
\hline Seedbed preparation & 135 & $14,84 \%$ \\
\hline Seeds (Inputs) & 270 & $29,67 \%$ \\
\hline Working force & 195 & $21,43 \%$ \\
\hline Harvest & 123 & $13,52 \%$ \\
\hline Post-harvest & 187 & $20,55 \%$ \\
\hline TOTAL & 910 & $100 \%$ \\
\hline
\end{tabular}

Source: Adapted from Ministerio de Agricultura del Perú, by MINAG, 2013.

As can be observed in table 6, the direct costs of production for one hectare of organic crop reached Us $\$ 910$. It is important to stress that the costliest items of production are the seeds, the workforce and the post-harvest step. According to the data provided ${ }^{3}$ and assuming an average yield per hectare of $1,100 \mathrm{~kg}$ and a sale price of us $\$ 2.61$ per $\mathrm{kg}$, the average benefit

3. The data used for this calculation is based on the 2011 yield figures from Puno, Peru because it is the most extensive area where quinoa is grown in Peru. 
per hectare would reach us $\$ 1,961$. This result allows us to identify a cost-price ratio of 2.15 , which means that in standard conditions of production, each dollar invested yields 2.15 times that amount. Therefore, it can be concluded that the production of quinoa is highly lucrative, more specifically so for associations of producers that, according to this same study, can increase their final price per $\mathrm{kg}$ by $60 \%$.

Table 7

Benefits per hectare

\begin{tabular}{cccccc}
\hline \multirow{2}{*}{ INCOME } & PRICE Kg & $\begin{array}{l}\text { YIELD } \\
\text { Kg/Ha }\end{array}$ & DIRECT COSTS Ha & BENEFITS PER HECTARE & Benefits/Costs \\
\hline US\$2.871 & US $\$ 2.61$ & 1.100 & US\$910 & US\$1,961 & 2,15 \\
\hline
\end{tabular}

Source: Adapted from Ministerio de Agricultura del Perú, by MINAG, 2013.

Finally, another advantage of farming quinoa is that it is more resistant to difficult climate conditions than other crops, which makes it possible to grow it in areas where other types of crops would not thrive, limiting in turn the risk of losses related to production (Table 7).

\section{Andean Crops and Socioproductive Practices}

In their analysis, Ríos and Solís (2009) point out that the western world concept of economic development has subdued ethnical diversity through the creation of socioeconomic categories reflecting its hegemonic power. Quijano (2000) contends that it is in Western Europe where these power structures were developed, segregating the "dominant" Europeans from the rest of "inferior races" considered archaic and pre-capitalist. As a consequence, this status quo has not only had an impact on the economy but also on societies, conveying the message that social issues can only be resolved through economic efficiency and capital markets.

Nonetheless, the concept of ethno-development has appeared from the Latin American perspective as an alternative to traditional hegemonic conceptions of the world and of production. Ethno-development was defined in the 1981 Declaration on Ethnodevelopment and Ethnocide of San José, Costa Rica as follows (Zolla \& Márquez, 2004):

By ethno-development we mean the extension and consolidation of the elements of its own culture, through strengthening the independent decision-making capacity of a culturally distinct society to direct its own development and exercise self-determination, at whatever level, which implies an equitable and independent share of power. This means that the ethnic group is a political and administrative unit, with authority over its own territory and decision-making powers within the confines of its development project, in a process of increasing autonomy and self-management.

From this quote we can understand that ethno-development goes beyond culture to the extent that it appears as an alternative to mechanisms fomenting social exclusion, in so far as ethno-development is based on a self-centered notion of development aimed at changing submission, consent and underestimation into self-esteem and recognition of the legitimacy of one's ethnicity as an efficient resource, and not exclusively as a sentimental reference to affiliation (Palenzuela, 2009).

As long as every citizen can freely set out their goals, the ensuing possibility for everyone to build their own processes leads them to share with their groups, communities and ethnicities autonomy, self-determination, honesty, transparency, fairness, solidarity, identity, self-assertiveness, respect for difference, participation to democracy, sustainability and preservation. These principles, which highlight the importance of community, have been the founding principles for indigenous communities to reach a harmonious life (Girardi, 1999).

As mentioned by Palenzuela (2009), this perspective of development allows to put off-center the dominant paradigm in order to contemplate alternative options in which fundamental democratic rights are recognized and where people can take their present and future into their own hands. Moreover, it supports the finding of new ways not to abandon basic values in a world that tends to homogenize individuals.

On the other hand, it refers to development as such, specifying that previous scenarios have to be 
changed into desirable situations following western world parameters. Nevertheless, in spite of development's variety of components (economic, social, sustainable, human), it must be stressed that the latter has been following a Eurocentric pattern characterized by subordination (Quijano, 2000).

From that subordination approach different paradigms or ways of thinking can emerge such as the "Buen vivir" (Good Life). Before going further in the analysis of the "Buen Vivir," it is essential to segregate what the thinking of original populations is - the very root of "Buen Vivir"- from other types of thinking such as "harmonic development" and identity development which are initiatives that do not include the essence of ancestral knowledge, let alone the implications they have for the creation of a new paradigm.

\section{Socioproductive Practices Based on "Buen Vivir": The Contribution of Andean People to Food Security, Sovereignty and Justice}

In the first place, it is essential to consider the cosmovision of native populations. Indeed, under this framework there is no mention to development, because, for these people, the requirements to reach an ideal life are far different from the western paradigms. The "Buen Vivir" has more to do with reuniting the spiritual and material conditions to reach harmony with the environment.

As stated by Huanacuni (2010), "Buen Vivir" goes beyond the mere satisfaction of needs and access to goods and services. In that regard, Buen Vivir cannot be reduced to the concept of development only because it is inadequate when compared to the Native populations' view. According to the Human Development Report published by the United Nations Development Programme in 2011, "Buen Vivir" encompasses aspects of life that allow the recognition of rights and expectations in such a way that more equality and more balance in social and economic areas are possible:

- Live in peace and control the land as a material and spiritual base for life

- Respect and care for Mother Earth

- Recognize and value identities, cultures that bear distinct values, notions and traditions equally
- Power to make decisions and participation over matters that directly concern them as indigenous people

Power and participation with others in the implementation of a model of State that reflects the vision and aspirations of indigenous people. Therefore, the perspective of "Buen Vivir" entails calling into question the contemporaneous ideas of development that put economic growth first and as a one-size-fitsall solution to poverty, knowing full well that the associated practices culminate in severe social and environmental damage (Gudynas, 2011).

The debate about "Buen Vivir" is based on three main ideas. The first one calls into question development theories, which are rooted in the concepts of progress and economic growth. The second dimension of the debate has to do with the ideas that allowed development theories to gain legitimacy. In that regard, under the perspective of "Buen Vivir" the relationships between people and nature are different from what development theories set out because the very understanding of life according to "Buen Vivir" does not factor in profitability and consumption. The third aspect of the debate has to do with the questioning of the speech that helps establish the dominant paradigm. "Buen vivir" entails a deep change about the concept of development per se that goes beyond mere corrections or adjustments. "Alternative developments" are not enough because they stick to the same understanding of progress (Gudynas, 2011).

Referring to socioproductive practices under the scope of "Buen Vivir" requires analyzing its liberating rationality, in which for example earnings are not considered an end per se but rather a means to reach collective quality of life. An equally important aspect of these practices under "Buen Vivir" has to do with the value in use of produced goods, i.e. production has to do more with the actual satisfaction of needs through reciprocity based on a balance between giving-receiving and giving back.

Similarly, it must be remembered that "Buen Vivir" fundamentally aims at reconnecting with nature. This is strictly different from the conventional perspective of development in which nature is no longer a source of resources, but something to be exploited. In this approach based on the respect for nature, production and commercialization relationships are redefined because the commercial value of nature, jobs and life is eliminated. To that extent, reciprocity becomes the keystone to social relationships, which 
leads to a different perception of economic processes (López-Cordova \& Marañón-Pimentel, 2013).

The relationship with nature is based on reciprocity and complementarity. In this relationship, groups tend not to have specialized production, making the most of the diversity of resources and developing agroecological practices. On the other hand, land is to be comprehended as more than just a physical space: it has to do with the passing of time through political, social and cultural dimensions.

Finally, although some production processes carry private elements, they are usually collective as far as the transformation, commercialization and distribution of products are concerned, which marks a huge difference with the capitalist rationality. Indeed, the production of value in use and social relationships exist because of the reciprocity based on a liberating rationality, which in turn crystallizes the coexistence of people with nature (López-Cordova \& Marañón-Pimentel, 2013).

\section{Conclusions}

The setting up of an industrial paradigm based on the development model has led to a concept of life based on production and consumption. Indeed, according to the prevailing neo liberal agenda, individuals and society as a whole have become consumerist and production-driven. That, in turn, has led identities to be defined through the creation of economic value rather than by their socio-cultural aspect.

The fact of reducing human beings to their functions of production and creation of value sheds light on the need to think differently in order to allow full self-realization. An example of an alternative to the status quo is reflected in ethno-development or "Buen Vivir" in which people can make their own decisions, which in turn makes it possible for them to reach their own ideal of progress and development, thus generating more than just material wealth.

To that extent, it is essential to safeguard Native Andean people's knowledge, more specifically so as far as crops are concerned, only because it becomes abundantly clear that this knowledge combined with Andean countries' comparative and potential competitive advantages would give them an edge on international markets, as well as bring a solution to the food security issue.

Under those circumstances, it is necessary to implement strategies to promote these crops (quinoa in the case in point), their variety and the many commercial possibilities they offer, not only for those countries suffering from food shortage, but also for developed countries. Consequently, countries producing quinoa must make the most of their competitive advantages. In that regard, setting up business associations in production and commercialization would be a good initiative to further increase the production of quinoa. Additionally, and in order to do so, the role of the State is important to help set up a relevant production framework.

Furthermore, it is equally important to promote quinoa worldwide. A point overlooked in this study is that quinoa, its benefits for health in general and byproducts are not well known at all.

On a final note, if quinoa-producing countries are to really benefit from its trade, it is essential for them to not only produce quinoa but also transform it into those byproducts with value added, in order for them, and small farmers more specifically, to economically and socially benefit from its production.

\section{References}

Álvez, A. (2011, November). Justicia alimentaria: Acceso a los alimentos suficientes. Noticias Aliadas Dossier Temático, 1. Retrieved from http://www.noticiasaliadas.org/objetos/informe/15PE_dossier_ja_na.pdf

Bojanic, A. (2011). La quinua: cultivo milenario para contribuir a la seguridad alimentaria. América Latina y el Caribe: FAO.

FAO. (1996, June). Informe de políticas: seguridad alimentaria. Retrieved from: ftp://ftp.fao.org/es/esa/policybriefs/pb_02_es.pdf

FAO. (2002, June 14). Movimiento Campesino Internacional. Retrieved from http://viacampesina.org/es/index.php/ temas-principales-mainmenu-27/soberanalimentary-comercio-mainmenu-38/316-declaracion-politica-foro-de-los-ongs-cumbre-fao

FAO. (2006, June). Informe de políticas: Seguridad alimentaria. Retrieved from ftp://ftp.fao.org/es/ESA/policybriefs/pb_02_es.pdf

FAO. (2011). Una introducción a los conceptos básicos de la seguridad alimentaria.Retrived from http://www.fao. org/docrep/014/al936s/al936s00.pdf.

FAO. (2012). Tendencias y perspectivas del comercio internacional de quinua. Retrieved from http://www.fao. org/3/a-i3583s.pdf.

FAO. (2013, November). Perspectivas alimentarias. FAO: Rome. Retrieved from http://www.fao.org/docrep/019/i3473s/ i3473s.pdf 
FAO. (2015). El estado de la inseguridad alimentaria en el mundo. Retrieved from http://www.fao.org/3/a-i4646s.pdf

FAO \& ALADI (2012). Tendencias y perspectivas del comercio internacional de quinua. Retrieved from http://www. fao.org/3/a-i3583s.pdf

Girardi, G. (1999). Entre la globalización neoliberal y el desarollo local sostenible. Quito: Ediciones Abya Yala.

Gudynas, E. (2011, February 28). Buen vivir: germinando alternativas de desarrollo. Alai. Retrieved from http:// alainet.org/active/48052

Huanacuni, F. (2010, February). Huacuni: Paradigma Occidental y Paradigma Indígena. Plataforma Buen Vivir. Retrieved from http://www.plataformabuenvivir.com/2011/07/huanacuni-paradigma-occidental-y-paradigma-indigena/

López-Cordova, D. \& Marañón-Pimentel, B. (2013). Racionalidades y prácticas socioproductivas alaternativas para el Buen Vivir. Retrieved from http:// www.economiasolidaria.org/documentos/racionalidades_y_practicas_socioproductivas_alternativas_ para_el_buen_vivir

Montoya, L. \& Martínez, L. (2005). Análisis de las variables estratégicas para la conformación de una cadena productiva de la quinua en Colombia. Revista Innovar, 15, 103-120.

MINAg. (2013, January). Ministerio de Agricultura del Perú. Retrieved from http://agroaldia.minag.gob.pe/biblioteca/download/pdf/agroeconomia/agroeconomia_ quinua.pdf
Obra Social "la Caixa". (2012). Justicia alimentaria: sembrando esperanza. Retrieved from https:// www.educaixa.com/documents/10180/38150/ Dossier+Justicia+alimentaria+cast.pdf/ed0c0c7514d6-4dc8-9c5d-936bff141c47

oxfam. (2011, June). Cultivar un futuro mejor. Justicia alimentaria en un mundo con recursos limitados. Retrieved from https://www.oxfam.org/sites/www. oxfam.org/files/growing-a-better-future-010611 es_0.pdf

Palenzuela, P. (2009). Mitificación del desarrollo y mistificación de la cultura: el etnodesarrollo como alternativa. Íconos, 33, 127-140. Retrieved from http://hdl.handle. net/10469/332

Pérez, J. C. (2014, October 8). La cadena productiva de la quinua. Cuarzo Económico. Retrieved from http:// www.cuarzoeconomico.org/la-cadena-productiva-de-la-quinua/

Quijano, A. (2000). El fantasma del desarrollo en América Latina. Revista venezolana de economía y ciencias sociales, 6(2), 73-90. Retrieved from http://www.cesla. uw.edu.pl/www/images/stories/wydawnictwo/czasopisma/Revista/Revista_1_quijano.pdf

United Nations (n.d.) Millenium Development Goals. Retrieved from http://www.un.org/millenniumgoals/ poverty.shtml

Zolla, C. \& Márquez E.Z. (2004). Los pueblos indígenas de México, 100 preguntas. Ciudad de México: unam. 